\title{
Levels of Integrating the ASSURE Model in Lesson Delivery of Selected Primary School Teachers in Nigeria
}

\author{
Adeyemi Adedapo \\ Department of Educational Foundations, National Open University of Nigeria, Abuja, Nigeria \\ Bolanle T. Opoola \\ Linguistics and Languages Department, Federal University, Oye-Ekiti, Ekiti State, Nigeria
}

\begin{abstract}
Scholars are aware of the fact that there have been many instances of teaching with no learning. One plausible reason for learning not to have taken place is when a teacher fails to design and creates conducive learning environments where changes in psychomotor, cognitive and affective behaviours can be accomplished effectively. But this can be corrected using the ASSURE model. Thus, the ASSURE model was investigated in this study as a method of lesson delivery to assess how far primary school teachers have gone in analyzing learners' characteristics, stating lesson objectives and utilizing instructional media. Three research questions guided the study. Fifty primary school teachers were purposively sampled and responded to a questionnaire during the 2016 FGN-UBEC/OYO-SUBEB Teacher Professional Development Capacity Building workshop. An appraisal of the sit-in-observations of this workshop shows the need for assessing the use of integrating the ASSURE model in lesson delivery. Results show that primary school teachers were below the average in terms of analyzing their pupils' characteristics before beginning their lessons and slightly above averages in the areas of systematically defining the lesson objectives and utilization of instructional media. It is recommended that the FGN-UBEC/OYO-SUBEB Teacher Professional Development Capacity Building workshops be extended to all categories of teachers in the UBEC scheme to update their knowledge to ensure effective teaching and learning situations.
\end{abstract}

Index Terms-ASSURE model, lesson delivery, instructional media, sit-in-observation

\section{INTRODUCTION}

An effective teacher is one who can create or contrive a rich and stimulating environment where learning can occur. It is not easy to define teacher effectiveness in classroom service delivery. This is so because of the complexity of the teaching-learning process and the different expectations and aspiration of the learners and the stakeholders in education. As an attempt to the definition of teacher effectiveness, Isaiah (2010) said it is the degree of proficiency and competence to which a teacher can achieve and demonstrate mastery and use of educational technology to attain set objectives in teaching-learning situations. Any teaching or learning that is result-oriented is termed as effective. A lesson whose objective is achieved is said to be an effective lesson. According to Bernard (2007), this effectiveness comes to focus through the student's result in examination. An effective lesson is not achieved without an effective teacher. An effective teacher uses good educational technology and methodologies. An effective teacher produces a practically oriented result where students do not only pass the examination but can practicalize their knowledge. For instance, a student who went through effective learning should be able to make learning autonomous and self-directed with the educational tools. He can produce and organize the material at his/her pace for maximum use and achievement in school and outside school. The use of an ASSURE model in lesson delivery is of interest in this study.

The Assure model is an instructional systems design process that was modified to be used by teachers in the regular classroom, to design and develop the most appropriate learning environment for their students (Megaw, 2006). The ASSURE model incorporates Robert Gagne's events of instruction to assure effective use of media in instruction. ASSURE is an acronym formed with the capitals of the model's steps. A - Analyze learners, S - State standard and objectives, S - Select strategies, technology, media and materials, U - Utilize technology, media and materials, R Require learner participation, and E - Evaluate and revise. According to Megaw (2006), the ASSURE model is the most convenient model for integrating the theories of instructional technology and research with practice. An instructional designer believes that the use of systematic design procedures can make instruction more effective, efficient and relevant than less rigorous approaches to plan instruction. To integrate the technology, education must require the systematical use of technology. According to Smaldino, Lowther and Russell (2012), a planning model called the ASSURE model is concerned with the use of technology systematically in lessons. For the teacher to get the maximum benefits out of the integration of media, he/she must systematically plan for it (Anulobi \& Akude, 2012). 
Hence, the need for the utilization of the ASSURE model, developed by Heinich, Molenda and Russel (1985) could be applied by the teacher for a systematic instructional delivery.

Baran (2010) investigated university-level students' experiences of designing lessons with an interactive whiteboard as an instructional medium. The sample consisted of 40 students who would be both moderators of technological resources in schools and computer teachers after graduation from university. In the design of a lesson process, the ASSURE instructional design model was their roadmap. The results showed that none of the students had used interactive whiteboards before the course. However, most of them knew interactive whiteboards from other courses, seminars, or the internet. Nearly half of the participants had some hesitations when they first learned that they were going to use interactive whiteboards in the course. After using it during a lesson, however, their opinions became positive. Besides, ASSURE instructional design model let them to progress systematically and step-by-step. It is instructive to find out whether or not Nigerian teachers can also benefit from the ASSURE model.

\section{OBJECTIVES OF THE STUDY}

This study has two main objectives. The first objective is exploratory. It is to report an assessment of a workshop aimed at gaining insight into lesson delivery of sampled teachers during the sit-in-observation. The second objective is to carry out a survey focusing on the identified teachers' needs during sit-in-observation.

\section{A. Reports of Sit-in-observations}

The authors of this paper were fortunate to serve as facilitator during the 2016 Federal Government of NigeriaUniversal Basic Education Commission (FGN-UBEC) Teacher Professional Development Capacity Building workshop. The aims and objectives of the workshop include among others: preparation of lesson plan; designing of instructional materials and effective utilization of materials; developing strategies for starting lesson; and lesson delivery during the sit-in-observation. During the sit-in-observation, the researchers did some focus observations of lessons taught by participants, took observation notes and conducted post-lesson debriefing interviews with only twenty participants assigned to mentor. Each participant was observed for three lessons (per week) which lasted for 13 weeks.

During the sit-in-observation, the researchers noted the following lapses:

(i) Participants failed to analyse their pupils' entry behaviours before beginning their lessons;

(ii) Many of the participants failed to revise the previous lesson with the pupils;

(iii) Not all participants prepared at least three lesson plans per week in any of the four core subjects (English Studies, Mathematics, Basic Science and Social Studies;

(iv) Lack of cognate experience on how to integrate instructional media;

(v) Participants failed to base their evaluation questions on the behavioural objectives.

(vi) Lack of classroom management and control.

It was discovered from a few instances seen during the classroom observation that instructional materials have the potential of helping teachers perform better if only extra efforts could be employed by them. For instance, a teacher who was observed made use of detergent and water stirred together to form bubble as improvised instructional material for snow. The use of improvised instructional material for snow made the lesson interesting and effective that the weakest pupil in the class was able to answer correctly questions posed after the lesson. In many of the cases, teachers who used only flashcards would normally teach about three-quarters of their lessons verbally and then, only about one quarter would be used for the display and use of the flashcards. This technique usually made English lessons dull and uninteresting and does not allow the use of verbal instruction to be well blended with instructional materials. This corroborates the study conducted by Ajayi-Dopemu (1986) in which he concluded that verbal instructions complemented with illustrations will be more effective than verbal instructions used alone.

The reasons for this observed ineffective teaching performance as given by various educators were varied and numerous: They include:

- $\quad$ Defective lesson- plans and weak delivery strategies (Udo \& Patrick, 2014).

- Lack of analyses of the learners' characteristics (Gage, 1971, Karagiannopoulou \& Entwistle, 2019).

- Lack of cognate experience on how to integrate instructional media into the implementation (Okolie, 2000, Adedapo, 2017).

- Ignorant of attending workshops and seminars on how to use the ASSURE model for integrating mediaand designing a lesson plan (Okolie, 2000; Maduabumi, 2003)..

\section{B. ASSURE Model and Teacher Effectiveness}

Given the observed ineffective teaching performance as mentioned above, the researchers of this study believed that teaching being an attempt to help someone acquire a change of attitude, knowledge, ideal, skills or appreciation, could be better carried out if a systematic methodology is correspondingly applied. Such method is the one which would make the learners become participatory learners, armed with skills to sharpen and update their scientific prowess to remain functional at all times. Thus, the ASSURE Model was investigated in this study, as a method of lesson delivery with a view of assessing how far primary school teachers have gone concerning its utilization for teaching effectiveness.

Specifically, the study sought: 
(i) the extent to which primary school teachers analyse their pupils' characteristics before beginning their lesson;

(ii) the extent to which primary school teachers systematically define their lessons objectives to reflect the three conditions (standard, condition and performance) necessary in the statement of lesson objectives;

(iii) the frequency to which primary school teachers utilize instructional media in teaching;

\section{RESEARCH QUESTIONS}

The following research questions were posed to guide the study:

(i) To what extent do primary school teachers analyse their pupils' characteristics before beginning their lessons?

(ii) To what extent do primary school teachers systematically define their lesson objectives to reflect the three conditions necessary in the statement of lesson objectives?

(iii) To what extent do primary school teachers utilize instructional media in teaching?

\section{METHODOLOGY}

The research design adopted for this study was a descriptive survey. It involves collecting data from a sample of 50 primary school teachers in Oyo West local government area of Oyo State, Nigeria. The participants were purposefully selected during 2016 FGN-UBEC Teacher Professional Development Capacity Building Workshop. Forty-two of the participants which represent $84 \%$ were female teachers, the remaining eight, that is $16 \%$, were male teachers.

The instrument for the study was a questionnaire titled: "Extent of the Use of Integrating ASSURE Model in Lesson Delivery" (EUIAMLD). The instrument is an 18-item structured questionnaire developed and administered by the researcher. It was adapted from the work of Udo and Patrick (2013). The questionnaire consists of two sections: A and B. Section A was designed to elicit personal information about the respondents while Section B was a four-point response format (Very Often $=4$, Often $=3$; Rarely $=2$; Not at All $=0$ ) of items made up of three parts $(\mathrm{A}, \mathrm{B}$ and C). Part A, dwelt on analysis of learners' characteristics before beginning the lesson and Part B dwelt on defining lesson objectives to reflect the three conditions. Part $\mathrm{C}$ dwelt on the utilization of instructional media in teaching. The 18 -item questionnaire was duly validated by two experts in educational technology and primary education, who offered valuable suggestions about the content validity. The internal consistency of the questionnaire was established using a split-half method and a reliability index of 0.83 was obtained. The collected data were analysed using frequency and mean scores.

\section{RESULTS AND FINDINGS}

Research Question 1: To what extent do primary school teachers analyse their pupils' characteristics before beginning their lessons? The data gathered are summarized in Table I.

TABLE I

PRIMARY SCHOOL TEACHERS' RANK ORDERED RESPONSES ON THE ANALYSIS OF PUPILS' CHARACTERISTICS

\begin{tabular}{|l|l|l|l|l|l|}
\hline S/N & Analysis of Pupils' Characteristics & CWS & $\begin{array}{l}\text { Mean } \\
\text { N }\end{array}$ & Rank & Decision \\
\hline 1. & Consideration of pupils' specific needs. & 165 & 3.30 & 1.07 & 1 \\
\hline 2. & $\begin{array}{l}\text { Consideration of pupils' range of background in terms of their } \\
\text { cultural and socio-economic factor. }\end{array}$ & 120 & 2.52 & 1.13 & 2 \\
\hline 3. & Consider their age differences. & 117 & 2.34 & 1.09 & 3 \\
\hline 4. & Consideration of pupils' learning styles & 117 & 2.34 & 1.03 & 3 \\
\hline 5. & Consideration of pupils' previous knowledge/ experience. & 115 & 2.30 & 1.09 & 5 \\
\hline 6. & Consideration of pupils' intellectual aptitude & 115 & 2.30 & .83 & 5 \\
\hline & Grand Mean Score & & $\mathbf{2 . 5 2}$ & 1.02 & Low Extent \\
\hline
\end{tabular}

Table I indicates that teachers' analyses of pupils' characteristics before beginning a lesson were low as virtually all the variables tested except in the aspects of considering the pupils' range of background and pupils' specific needs are above the acceptable mean score of 2.50. Pupils' intellectual aptitude, differences in age, specific needs and learning styles were at very low levels. Meanwhile, the grand mean score here shows that the teachers were within the average in terms of analyzing their pupils' characteristics before beginning their lessons.

Research Question 2: To what extent do primary school teachers systematically define their lesson objectives to reflect the three conditions necessary in the statement of lesson objectives? The data gathered to answer this question are summarized in Table II. 
TABLE II

Primary School TeACHERS' MEAN RESPONSES ON SySTEMATIC DEFINITION OF LEARNING OBJECTIVES

\begin{tabular}{|l|l|l|l|l|l|}
\hline S/N & B. Systematic Definition of Lesson Objectives & CWS & Mean & Rank & Decision \\
\hline 1. & Specify the content. & 184 & 3.68 & 1.17 & 1 \\
\hline 2. & Specified in measurable and observable terms & 178 & $\mathbf{3 . 5 6}$ & $\mathbf{1 . 1 2}$ & $\mathbf{2}$ \\
\hline 3. & Directed to the target learners & 143 & 2.86 & 1.13 & 3 \\
\hline 4. & $\begin{array}{l}\text { Specified to indicate the condition that will be used to } \\
\text { judge learners' performance }\end{array}$ & 121 & 2.42 & 1.01 & 4 \\
\hline 5. & Specified to reflect the affective domain & 110 & 2.20 & .86 & 5 \\
\hline 6. & $\begin{array}{l}\text { Specified to indicate the acceptable standard of } \\
\text { performance }\end{array}$ & 2.02 & .99 & 6 \\
\hline & Grand Mean Score & & $\mathbf{2 . 7 9}$ & $\mathbf{1 . 0 7}$ & \\
\hline
\end{tabular}

Table II indicates the extent to which primary school teachers systematically define their lesson objectives. The outcome reveals that participants who are primary school teachers clearly stated their lesson objectives to specify the content, making it measurable and observable; averagely specified the pupils to which the objectives are directed; and also highly specified the lesson content in line with the lesson objectives; and also achieved within the stipulated time in that order.

However, the response of the participants in defining the lesson objectives to reflect the affective domain, indicate the acceptable standard of performance and show the conditions that would be used to judge their learners' performance all fall below average. This indicated that the three factors are rarely stated in their lesson objectives. The overall mean for this section was 2.79 which was above the acceptable mean. The implication of this is that the participants were rated above the average in terms of systematically defining their lesson objectives.

Research Question 3: To what extent do primary school teachers utilize instructional media in teaching? The data gathered are summarized in Table III.

TABLE III

PRIMARY SCHOOL TEACHERS' MEAN RESPONSES ON UTILIZATION OF InSTRUCTIONAL Media In TEACHING

\begin{tabular}{|c|c|c|c|c|c|c|}
\hline $\mathrm{S} / \mathrm{N}$ & C. Utilization of Instructional Media in Teaching & CWS & Mean & SD & Rank & Decision \\
\hline 1. & $\begin{array}{l}\text { Consider the interests and needs of the pupils in selecting the } \\
\text { instructional media? }\end{array}$ & 164 & 3.28 & 1.10 & 1 & High Frequency \\
\hline 2. & Source for instructional media? & 104 & 2.08 & .98 & 2 & Low Frequency \\
\hline 3. & $\begin{array}{l}\text { Display basic knowledge and skills for effective utilization of } \\
\text { instructional media? }\end{array}$ & 98 & 1.96 & 1.02 & 3 & Low Frequency \\
\hline 4. & Utilize enough time for instructional media in teaching? & 97 & 1.94 & 1.01 & 4 & Low Frequency \\
\hline 5 & $\begin{array}{l}\text { Utilize instructional materials to the appropriate level of } \\
\text { difficulty? }\end{array}$ & 96 & 1.92 & .92 & 5 & Low Frequency \\
\hline \multirow[t]{2}{*}{6.} & $\begin{array}{l}\text { Attend seminar/workshop /conference on effective use of } \\
\text { instructional media? }\end{array}$ & 58 & 1.16 & 1.09 & 6 & Low Frequency \\
\hline & Grand Mean Score & & 2.05 & .98 & & \\
\hline
\end{tabular}

Table III indicates that the participants always considered the interest and needs of the pupils in the selection of instructional media with mean of 3.28 which was to a high extent. However, the participants indicated that the frequency at which teachers attended workshop/seminar/conference, sourced for instructional media, utilized instructional media, encountered obstacles in the course of utilization and displayed basic knowledge and skills with respective means of $1.16,2.08,1.92,1.94$ and 1.96 were at very low frequency. The overall mean for this section was 2.05 indicating that primary school teachers exhibit a low frequency in effective utilization of instructional media.

\section{DISCUSSION}

The findings on research question one reveal that pupils' characteristics such as pupils' intellectual aptitude, age differences, specific needs and learning styles were not adequately analysed by primary school teachers before beginning their lesson as against what the ASSURE model emphasizes. The result, however, reveals that variables like pupils' cultural and socio-economic background and specific needs were given consideration. This might not be unconnected with the fact that teachers are aware of the tribe of the pupils and the economic status of their parents as these influenced their decision. This result is not in conformity with the assertion of Heinich, Molenda, Russell and Smaldino (2001), Baran, (2010) who noted that for the ASSURE model to be properly utilized, it is essential to first think about the learners and their general characteristics, academic levels, skills, and styles of learning before beginning a lesson.

The study also reveals that primary school teachers scarcely or hardly reflect the affective domain in their lesson objectives, hardly indicate the acceptable standard of performance in lesson objectives and also hardly indicate the conditions that would be used to judge their learners' performance. It means that teachers lack competencies in stating instructional objectives. The result conforms to the findings of Ifegbo (2009), Udo and Patrick (2014) who reported that 
teachers lacked competencies in stating objectives in affective domain for lessons and they also fail to indicate conditions and degrees of performance while stating objectives for the lesson.

It was indicated in the findings that primary school teachers exhibit to a low extent effective utilization of instructional media which the adoption of the ASSURE model emphasizes. One plausible reason for this outcome is that of non-availability and poor usage of instructional media as majority of the sampled respondents indicated that it was on the rare occasion that they sourced for instructional media for instruction. On this note, one could say that the availability and accessibility of instructional media resources are important factors that determine the frequency with which primary school teachers use instructional media. The use of instructional media is always necessary irrespective of the subject or the level that one teaches. It, therefore, suggests that the extent to which primary school teachers use instructional media is related to the availability of teaching media in the classroom. From the reviewed literature on the usage of media and resources available for teachers to use, all studies reported poor usage of the teaching media by teachers. Very significant one of them is that of Onansanya, Adegbija, Olumorin \& Daramola (2008) which reported a woeful usage of media at $2 \%$ by teachers. Olumorin (2008) reported that the majority of the lecturers had poor usage of the educational resources and that they use them less frequently. Piper (2003) reported a significant influence of knowledge on novice teachers' classroom uses of instructional media. Evidence suggests that the teachers lacked the required skills and knowledge to use instructional media in the classroom. Borko and Putnam (cited in Udo \& Patrick, 2013) opined that teachers' poor attitude towards the use of instructional media in the classroom is sometimes attributed to lack of knowledge in using visual materials and media. They get reluctant in getting acquainted with different innovations because they feel that such will invade their professional autonomy and expose their inadequacy.

\section{CONCLUSION AND RECOMMENDATION}

The integration of ASSURE model in lesson delivery is a way to ensure that the learning environment is appropriate for students as it can be used in lesson plans to improve teaching and pupils' learning while using instructional media. This is based on the fact that teachers would be able to analyse their pupils' characteristics before beginning their lesson; systematically define their lessons objectives to reflect the three standard, condition and performance necessary in the statement of lesson objectives and effectively utilize instructional media in teaching among others. However, based on the findings of this study it is evident that:

(i) teachers were just within the average in terms of analyzing their pupils' characteristics before beginning their lessons;

(ii) teachers rated themselves slightly above the average in terms of systematically defining their lesson objectives; and

(iii) teachers exhibit a low level of effective utilization of instructional media.

It is recommended that the FGN-UBEC/OYO-SUBEB Teacher Professional Development Capacity Building workshops be focused on ASSURE Model and be extended to all categories of teachers in the UBEC scheme to ensure effective teaching and learning situations. Particular attention needs to be paid to the effective utilization of instructional media.

\section{REFERENCES}

[1] Adedapo, A. (2017). Media technology exposure and the Nigerian primary school children. NOUN Journal of Education, 4, 8286.

[2] Ajayi-Dopemu, Y. (1986). The place of Educational Technology in Physical Education. West African Journal of Physical and Health Education, 4(2). Pp. 89 - 95.

[3] Anulobi, J.C. \& Akude. (2012). Integration of Instructional Materials in the Classroom Lesson Delivery: A lead paper presented at the NAEMT regional conference in Owerri, Imo State.

[4] Baran, B. (2010). Experiences from the process of designing lessons with interactive whiteboard: ASSURE as a road map. Contemporary Educational Technology, 1(4), 367-380.

[5] Bernard, J. R. (2007). Active Learning in the Maths Classroom Implication to Secondary School Maths. A paper presented at a workshop for the retraining of Mathematical Science Technology in Plateau State.

[6] Gagne, R.M. (1971). The Condition of Learning. New York: Holt, Rinehard and Winston.

[7] Heinich, R. M., Molenda, M. Russell, J.D. \&Smaldion, S.F. (2001). Instructional Media and Technologies for Learning (7 $7^{\text {th }}$ ed.), New York: Macmillan Publishing Company.

[8] Heinich, R., Molenda, M. \& Rusell, J.D. (1985). Instructional Media and the New Technologies of Instruction. New York: John Wiley and Sons Publishers.

[9] Ifegbo, P. C. (2009). Competencies required by primary school teachers in the planning and utilization of instructional materials for quality assurance, Journal of Educational Media and Technology and Instruction,1 (1), pp. 87-92.

[10] Isaiah, O. (2010). Beyond the Stereotype Thoughts and Reflections on Education. Lagos: The CIBN Press Limited.

[11] Karagiannopoulou, E. \& Entwistle, N. (2019). Students' learning characteristics, perceptions of small-group university teaching, and understanding through a "meeting of minds", Front Psychol, 10. Retrieved on November 9, 2019, from ncbi.nlm.nih.gov/pmc/articles/PMC6448036.

[12] Maduabunmi, B.O. (2003). Towards the Optimal Utilization and Management of Resources for the Effective Teaching and Learning of Physics in Schools. Proceedings of the $41^{\text {st }}$ Annual Conference of the Science Teachers' Association of Nigeria, (STAN), University of Lagos, Nigeria, pp.: 215-220. 
[13] Megaw, A. (2006). Deconstructing the Heinch, Molenda, Russell and Smaldino Instructional Design Model. Retrieved on November 9, 2014, from https://ipislam.edu.my/ kplir/Bacaan/Assure/idm_angela.pdf.

[14] Okolie, T.O. (2000). Teacher competence in evaluation of instruction programmes in austere times: the case of mathematics. In Imogie, I., Onyejemezi, D.A., Mkpa, M.A. \& Anukam, I.L.. (eds.), Trend and Research in Educational Technology. Okitipupa: Ebun Ola Printers Nig. Ltd.

[15] Olumirin, C.O. (2008). An Investigation of Tertiary Institution Lecturers' Attitude To Competence In And Use of Computers In Kwara State, Nigeria: Unpublished PhD Thesis, Science Education Department, Faculty of Education, University of Ilorin, Ilorin, Nigeria.

[16] Onansanya, S.A., Adegbija, M.V., Olumorin, C.O. \& Daramola, F.O. (2008). Education reforms and assessment of teachers' competence in instructional media technology use in junior secondary schools in Kwara State. Education Reforms in Nigeria: Past, Present and Future, Stirlling-Horden Publishers Ltd., 259-271.

[17] Piper, D. (2003). The relationship between leadership, self-efficacy, computer experience, attitudes and implementation of computers in the classroom. In C. Crawford, D. Willis, R. Carlsen, I. Gibson, K. Meferrub, J. Prince \& R. Weber (Eds.), Proceedings of Society for Information Technology, 1057-1060.

[18] Smaldino, S., Lowther, D., \& Russell, J. (2012). Instructional Technology and Media for Learning (10th Ed.). Upper Saddle River, NJ: Prentice-Hall.

[19] Udo, A.L. \& Patrick, J.U. (2013). System approach in science lesson delivery: An assessment of state colleges of education science lecturers in Akwa Ibom and Cross Rivers. Journal of Educational Media and Technology, 18 (1), pp. 106-113.

Adeyemi Adedapo is a lecturer of Educational Technology at the National Open University of Nigeria, Abuja, Nigeria. He attended University of Ibadan, Ibadan, Nigeria for his first and second degrees and later proceeded to Olabisi Onabanjo University, Ago-Iwoye, Ogun State, Nigeria for his doctorate degree in Educational Technology. He has taught a variety of courses leading to the award of Nigeria Certificate in Education and Bachelor Degree in Education while he was in Emmanuel Alayande College of Education, Oyo, Oyo State, Nigeria. He started his teaching career as an assistant lecturer in the year 2002 and rose to the position of principal lecturer before joining the National Open University of Nigeria as a Lecturer I in 2017. He has published articles in reputable journals in both national and international levels. His research interests are teacher education, educational technology, microteaching, open and distance learning and e-learning.

Bolanle T. Opoola is a Professor of Linguistics at the Federal University, Oye-Ekiti, Ekiti State, Nigeria. He attended University of Calabar, Cross River State, Nigeria for his first, second and doctorate degrees with speciality in Applied Linguistics. Prior to joining the Federal University, Oye-Ekiti, he taught a variety of courses at the Colleges of Education (Federal College of Education, Obudu, Cross River State and Federal College of Education (Special), Oyo, Oyo State, Nigeria). He served as Head of Department, Dean, Director of Academic Planning and Deputy Provost of his former college. He is the current Dean, Faculty of Arts at the Federal University, Oye-Ekiti and he supervised several degree projects, masters' dissertations and as well as ongoing thesis. He is a member and chairman of various committees at the university level and chairman/member of editorial boards and appointed reviewer of international journals. He has published several articles and attended conferences in both national and international levels. 